\title{
Why One-shot Information Literacy Sessions Are Not the Future of Instruction: A Case for Online Credit Courses
}

\author{
Yvonne Mery, Jill Newby, and Ke Peng
}

\begin{abstract}
This paper reports on a research project that examined the test scores of students who took part in an online information literacy course. Researchers analyzed the pre- and post-test scores of students who received different types of instruction including a traditional one-shot library session and an online course. Results show that students who participated in the online course demonstrated significant improvement in their test scores compared to the other students. This study shows freshman students' needs for more comprehensive information literacy instruction. It also shows that information literacy instruction can be effective when delivered online.
\end{abstract}

\section{Background}

The University of Arizona Libraries (UAL) has had a decades-long history of working with the English Department's Freshman Writing Program in support of the goals of the General Education Curriculum. Until recently, information literacy (IL) instruction for composition courses had traditionally taken the form of one-shot, fifty-minute sessions for individual course sections. However, beginning in late 2008, the libraries strategically began moving more of their instructional activities online in an effort to more efficiently and effectively deliver information literacy instruction to a greater number of students in an anytime/anywhere environment. With a yearly increase in student enrollment and a decrease in librarians available to teach face-to-face, the libraries needed a means to reach over 5,000 students enrolled in the program each year. To this end, the libraries developed its first online credit-bearing course, the Online Research Lab (ORL).

The ORL is a one-credit information literacy course offered to first-year students enrolled in a required English Composition course, English 102, at the University of Arizona. The ORL course was developed by librarians and has been offered to students since the fall of 2009. Students take the ORL course entirely online over a ten-week period. It is taught by trained graduate assistants from different university departments.

Yoonne Mery is Instructional Design Librarian and Jill Newby is Associate Librarian at University of Arizona Libraries; e-mail: meryy@u.library.arizona.edu, newbyj@u.library.arizona.edu. Ke Peng is Assistant Professor in Asian Studies at Western Kentucky University; e-mail: ke.peng@wku.edu. (C) 2012 Yvonne Mery, Jill Newby, and Ke Peng, Attribution-NonCommercial (http://creativecommons.org/licenses/ $b y-n c-s a / 3.0 /)$ CC BY-NC 
The Association of College and Research Libraries Information Literacy Standards were used in the development of course content, and course topics range from narrowing and selecting topics to using databases effectively. Coursework in the ORL was specifically designed and paced to support the assignments and learning objectives of the English 102 syllabus. A more detailed account of the development of the course is available in Mery et al. ${ }^{1}$

UAL instructional librarians needed to determine if this new course would be as effective as the abandoned traditional one-shot session. Researchers (in this instance, the librarians who developed the course) needed to know where students were struggling so they could make adjustments to the course content. In addition, there was doubt among librarians that this new format could be as effective as the face-to-face method where students' questions could be answered immediately and where meaningful contact was the norm. It is not uncommon for this type of doubt and apprehension to take place when online instruction is introduced in the library. ${ }^{2}$ To address these concerns, researchers designed a research study that would allow them to answer the following research questions:

1. Does the type of information literacy instruction (one-shot library session and an online course) students receive affect their learning outcomes?

2. If there is evidence of learning across different types of information literacy instruction, does the type of instruction affect skill sets differently?

\section{Literature Review}

The library literature for the past twenty years has provided a great deal of evidence that online instruction is as effective as traditional (face-to-face) library instruction. ${ }^{3}$ Online instruction is seen as a solution for provision of instruction for a seemingly never-ending increase in student enrollment and campus administrations' demand for online instruction. ${ }^{4}$ The use of online tutorials provides a consistent standardized instructional delivery mechanism as well as a selfdirected engaging learning environment. ${ }^{5}$ The online environment lends itself to providing students with instant feedback on their learning. ${ }^{6}$ For students who can only take online classes, such as distance students and nontraditional students, providing instruction in an online environment allows this group of students the same opportunities to learn information literacy skills and concepts. ${ }^{7}$

Zhang, Watson, and Banfield ${ }^{8}$ conducted a systematic review of academic library studies on the effectiveness of computer-assisted instruction (CAI) vs. face-to-face instruction published between 1990 to 2005. Of the ten studies that met the authors' criteria, nine of the studies concluded that CAI and in-person instruction were equally effective in teaching basic library skills. Further, those studies that included evaluating students that did not have any library instruction, both CAI and face-to-face instruction, provided evidence that there were gains in student learning compared to those students with no instructional intervention.

The tenth study in the Zhang,Watson, and Banfield review found that first-year sociology students who had in-class instruction with a hands-on exercise did better on the post-test on average than those students taking the online tutorial. ${ }^{9}$ One of the research design problems with this study is that the pre-test occurred at the beginning of the session and the posttest occurred at the end of the session. Since there was very little time between tests, it is difficult to determine if there was any long-term acquisition of IL skills. In the Zhang, Watson, and Banfield review, there were four studies where the post-test was given immediately after the instruction. For the other six studies, the time lapse ranged from less than a week to six weeks later. Only one study in the review used different pre- and post-test 
questions. The authors note that it is better to use different questions in the post-test when there is a short time period between the pre- and post-tests. Using a different set of questions that test the same concepts in the post-test can provide evidence that students are learning the concepts rather than just memorizing the answers.

In another instance, Silver and Nickel ${ }^{10}$ compared 300 students' post-test scores in a undergraduate psychology course. They found that the online tutorials and in-class instruction were equally effective when measured on a post-test.

Some library research studies have sought to determine the comparative effectiveness of three different modes of instruction: online, in-class and a hybrid model of both online and in-class instruction. ${ }^{11}$ Anderson and May ${ }^{12}$ administered pre- and post-tests to 103 undergraduates in a face-to-face class, an online tutorial with a face-to-face presentation, and a totally online tutorial taken independently. Both the pre/post-test analysis showed that students did not significantly differ in their library research skills. The pre-test scores were quite high and the post-tests showed modest gains. This could be due to the nature of the questions. The authors did not indicate that the test items were analyzed for validity or reliability. For the Library Research exercise, students had to select a topic to present and conduct a keyword search using Boolean operators to locate references. Analysis showed that the students did not differ significantly in the results on the Library Research exercise. The authors concluded that the students may have previously had some IL instruction in their Freshmen English course. In addition, students had to create a persuasive presentation that required finding supporting information and using APA citation style for their bibliography. Students who had online instruction did better in the persuasive presentation than the students in the other two instructional environments. The authors suggest that this probably had more to do with the evaluation and synthesis skills taught by the students' graduate teaching assistant than the information literacy module that focused on information-seeking skills. The authors also note that their low sample size (103 students) prevented them from making any generalized conclusions.

Academic librarians at Oakland University (OU) in Rochester, Michigan ${ }^{13}$ conducted a study comparing the effectiveness of three different methods of delivering online instruction to Composition II students: online instruction through WebCT, in-class presentations, or a hybrid model of both online tutorials through WebCT and in-class presentations. There were 224 students in the study conducted over a one-week period. All students took pre- and post-tests. All students in the study, regardless of delivery method, showed a statistically significant improvement in test scores from pre- to post-tests. Students who experienced the blended approach, both in-class and online instruction, showed the most gains in learning.

The result of this study and others add to the body of knowledge about the effectiveness of online and blended learning and confirms a recent U.S. Department of Education ${ }^{14}$ report that analyzed research studies for the effectiveness of online instruction. Their findings were that online instruction, especially when used in a blended approach, can be just as effective as face-to-face instruction if sound pedagogical techniques are employed. Teaching techniques that were most successful were time on task, additional learning materials, and opportunities for student collaboration.

While it is important to establish that online instruction is as effective as faceto-face instruction, and our study corroborates this as well, the more important impact comes from students taking a credit course rather than the traditional 'one-shot' instruction session. One-shot instruction sessions by their nature cannot provide students with more than an introduction to basic library skills. ${ }^{15}$ Students need sustained use of library 
research tools to gain IL competencies. ${ }^{16}$ In a writing class, such as a freshman composition course, what cannot be taught in a one-class session is the "...essential connections between research contexts and writing processes. ${ }^{17 \prime \prime}$ A fifty minute faceto-face session can focus on information retrieval but not on the more broad and complex concepts of seeking background information, identifying key terms and the exploration needed to complement the writing process in a recursive manner. Badke $^{18}$ also notes that information literacy competencies take more time and practice than can be garnered in a one-shot or 50 minute class session. As Owusu-Ansah ${ }^{19}$ describes in his well cited paper, information literacy encompasses a broader set of concepts surrounding use of information, such as synthesizing information, evaluating info sources and using information in a legal and ethical manner.

Wang, ${ }^{20}$ in his study that measured the effectiveness of a credit course, found that students who participated in a library credit course used more scholarly sources in their papers and received higher grades on their papers a year after taking the course. A comparison of the learning outcomes of students in an online information literacy credit course and the same course offered face-to-face at the University of Rhode Island showed that the online students performed as well as students in the face-to-face course. ${ }^{21}$ An earlier iteration of the information literacy assessment at URI Libraries and faculty anecdotes demonstrated that the credit course was valuable in gaining information literacy competencies. ${ }^{22}$ Mulherrin et al. ${ }^{23}$ describes the impact of a required online credit course at the University of Maryland University College that was developed for the General Education Program. While the ratio was $1 / 100$ instructor/students in the online information literacy course, librarians agreed that, to provide a "a systematic information literacy education that is accessible to all," the course must be a required credit course. Analysis of the pre- and post-tests showed that the students made significant improvement on the post-test (17-18 percentage points) The authors concluded that providing a credit course online can be a successful method for teaching students information literacy. Through the student evaluations, the authors learned that students wanted to take the course to receive credit toward their degrees.

Others have argued that there are many barriers to teaching a library credit course. It is often quite difficult to introduce a new credit course into the curriculum, especially into a general education program. ${ }^{24}$ However, if the library does succeed in offering credit courses, this can add validation that the library is part of the teaching academy and can increase the status of librarians as faculty. ${ }^{25}$ Additionally, many libraries face resource constraints with insufficient staff to create and teach a credit course. ${ }^{26}$ Another concern expressed by both librarians and teaching faculty moving away from face-to-face instruction to online learning is a loss of personal contact with librarians and losing a connection to the library as place. ${ }^{27}$

There are other considerations to be made when determining best use of staff resources. For example, it takes considerable time and money to develop online tutorials and courses, and there is a need for continual updating. ${ }^{28}$ However, online courses are continuing to grow; and, for some academic libraries, there is a campus push to create more online courses. ${ }^{29}$ While extra time and effort is necessary in developing and implementing an online course, over time, maintenance of the online course can save the time of the instructor and provides students with much more flexibility and convenience to fully explore and learn information literacy techniques and principles. ${ }^{30}$

\section{Methodology}

In the spring of 2010, researchers designed a randomized control-group pre-test/ post-test study to evaluate the effectiveness of three types of instruction. Type 1: Students received information literacy in- 
struction from their English Composition instructor as part of their regular course curriculum. English instructors had been previously trained by librarians in the use of the English Composition Subject Guide and recommended databases for students. Type 2: Students received one 50-minute information literacy session by a librarian. This session consisted of an introduction to searching basics, the English Composition Subject guide, and two relevant databases. Type 3: Students took part in the ORL course. A total of 660 students participated in the study, and students were grouped as follows:

Control Group: Twenty-eight students enrolled in English 101 who did not receive any type of information literacy instruction but did participate in preand post-testing. These students were recruited by their English instructor and received gift cards as an incentive to complete both the pre- and post-tests.

Treatment Group 1: Three randomly selected sections of English 102 that received instruction from their English Composition instructors. A total of thirty students participated in both pre- and post-testing. These students were recruited by their English instructor and received gift cards as an incentive to complete both the pre- and post-tests.

Treatment Group 2: Three randomly selected sections of English 102 who received instruction from a librarian. A total of thirty-two students participated in both pre- and post-testing. These students were recruited by their English instructor and received gift cards as an incentive to complete both the pre- and post-tests.

Treatment Group 3: Twenty-nine sections of the ORL course. A total of 570 students completed both pre- and posttests. Students were required to complete the tests as part of their coursework.

The development of the pre- and posttests, including the assessment of the reliability and validity of individual test items, is addressed in Mery, Newby, and Peng. ${ }^{31}$ This study shows that test items had a high reliability rating and were correlated to SAILS, a standardized test of information literacy. Test items were not specific to the ORL course but rather consisted of information literacy items that were more global in nature. Test items addressed one of eight different skill sets developed by Project SAILS: ${ }^{32}$

1. Developing a research strategy.

2. Selecting finding tools.

3. Searching.

4. Using finding tool features.

5. Retrieving sources.

6. Evaluating sources.

7. Documenting sources.

8. Understanding economic, legal, and social issues.

The researchers used test items to construct 7 different tests that were randomly distributed among different groups. The pre-test consisted of twenty-five multiple-choice questions, while the posttest consisted of forty multiple-choice questions. Both tests were administered online through the university's course management system, Desire to Learn. Students had two hours to complete the tests, which could only be taken once.

Dimitrov and Rumrill ${ }^{33}$ point out that this pre-test/post-test research design suffers from two types of threats to internal validity (maturation and history) and one major threat to external validity (the interaction of pre-testing and treatment). A maturation threat occurs when the observed effect or difference is due to participants growing older, more experienced, and more skillful between the pre-test and post-test and not as a result of the treatment. These factors are controlled in this study and will be addressed in the analysis.

\section{Results and Discussions}

The authors analyzed the data using the SPSS statistical package. The assumption for the analysis of covariate (ANCOVA) was violated due to variability in the pretest. Instead, a more complicated two-way repeated-measures analysis of variance (ANOVA) was conducted to evaluate the changes or gains that occurred to each group from the time of the pre-test 
to the time of the post-test. The independent variable, or between-subject factor, was the four groups; and the dependent variable, or within-subject factor, was students' scores in the pre- and post-tests.

A total number of 660 students participated in both the pre- and post-tests. A significance level of .05 was chosen since there were an uneven number of participants in each group. The two-way ANOVA showed that there were significant differences in students' average IL performance among the four groups: $\mathrm{F}(3,656)=23.85, p<.001$. There was also significant difference between the overall pre-test scores and post-test scores: $\mathrm{F}(1,656)=25.75, p<.001$. The interaction between the student groups and tests was also significant: $\mathrm{F}(3,656)=32.23, p<.001$. Conceptually, a significant interaction is observed when the change or gain one group makes is statistically much greater than the other group(s). Interaction also occurs when one group makes improvement from pre-test to post-test while another group deteriorates. No interaction is observed if the change, or gain, in one group is the same as the change or gain in the other groups. In this case, the significant interaction between the student groups and tests suggested different levels of change or gain from pre-test to post-test among the four treatment groups. However, this significant interaction did not reveal which group means differ and how much the means differ from each other. To address these questions and understand what contributed to the significant interaction, we conducted a series of follow-up analyses and post hoc comparisons.

The mean scores on the pre-test and post-test for each of the experimental groups and the control group are included in table 1 . If we focus on the change that occurred to each group from the time of the pre-test to the time of the post-test, without comparison, no significant difference was observed in the IL skills of students in the control group $(\mathrm{F}(1,27)=0.24, p=.626)$ or Treatment Group $1(\mathrm{~F}(1,29)=0.02, p=$ .877). However, we did find significant acquisition of IL skills among students in Treatment Group $2(\mathrm{~F}(1,31)=13.15, p=.001)$ and Treatment Group $3(\mathrm{~F}(1,569)=805.40$, $p<.001)$. In other words, only students in Treatment Groups 2 and 3 made significant progress or achievement in their IL skills.

If we focus on students' overall performance on both tests, all groups performed equally poorly at the time of the pre-test and there were no significant differences among the four cohort groups: $\mathrm{F}(3,659)$ $=0.48, p=.698$. However, students' IL performance was significantly variant

\begin{tabular}{|c|c|c|c|c|c|c|c|}
\hline \multicolumn{8}{|c|}{$\begin{array}{c}\text { TABLE } 1 \\
\text { Descriptive Statistics of Information Literacy Achievement by Experiment } \\
\text { Groups }\end{array}$} \\
\hline \multirow[t]{2}{*}{ Test } & \multirow[t]{2}{*}{$\begin{array}{c}\text { Treatment } \\
\text { Groups }\end{array}$} & \multirow[t]{2}{*}{$\mathbf{N}$} & \multirow[t]{2}{*}{ Mean } & \multirow[t]{2}{*}{$\begin{array}{c}\text { Std. } \\
\text { Deviation }\end{array}$} & \multirow[t]{2}{*}{$\begin{array}{l}\text { Std. } \\
\text { Error }\end{array}$} & \multicolumn{2}{|c|}{$\begin{array}{l}\text { 95\% Confidence } \\
\text { Interval }\end{array}$} \\
\hline & & & & & & $\begin{array}{l}\text { Lower } \\
\text { Bound }\end{array}$ & $\begin{array}{l}\text { Upper } \\
\text { Bound }\end{array}$ \\
\hline \multirow{4}{*}{ Pre-test } & Control Group & 28 & $51.48 \%$ & $10.09 \%$ & $1.91 \%$ & $47.57 \%$ & $55.40 \%$ \\
\hline & Treatment 1 & 30 & $46.94 \%$ & $13.92 \%$ & $2.54 \%$ & $41.75 \%$ & $52.14 \%$ \\
\hline & Treatment 2 & 32 & $50.65 \%$ & $12.16 \%$ & $2.15 \%$ & $46.27 \%$ & $55.04 \%$ \\
\hline & Treatment 3 & 570 & $49.84 \%$ & $16.01 \%$ & $0.67 \%$ & $48.48 \%$ & $51.11 \%$ \\
\hline \multirow{4}{*}{ Post-test } & Control Group & 28 & $50.18 \%$ & $13.71 \%$ & $2.59 \%$ & $44.86 \%$ & $55.49 \%$ \\
\hline & Treatment 1 & 30 & $46.50 \%$ & $17.77 \%$ & $3.24 \%$ & $39.87 \%$ & $53.14 \%$ \\
\hline & Treatment 2 & 32 & $60.00 \%$ & $15.86 \%$ & $2.80 \%$ & $54.28 \%$ & $65.72 \%$ \\
\hline & Treatment 3 & 570 & $73.31 \%$ & $14.39 \%$ & $0.60 \%$ & $72.12 \%$ & $74.49 \%$ \\
\hline
\end{tabular}


TABLE 2

Multiple Comparisons of the Cohort Groups in the Post-test (Bonferroni)

\begin{tabular}{|l|c|c|c|c|c|c|}
\hline (I) Group & (J) Group & $\begin{array}{c}\text { Mean } \\
\text { Difference } \\
(\mathbf{I}-\mathbf{J})\end{array}$ & \multirow{2}{*}{$\begin{array}{c}\text { Std. } \\
\text { Error }\end{array}$} & & Sig. & \multicolumn{2}{|c|}{$\begin{array}{c}\mathbf{9 9 . 2 \%} \text { Confidence } \\
\text { Interval }\end{array}$} \\
\cline { 5 - 7 } & & $\begin{array}{c}\text { Lower } \\
\text { Bound }\end{array}$ & $\begin{array}{c}\text { Upper } \\
\text { Bound }\end{array}$ \\
\hline $\begin{array}{l}\text { Treatment } \\
\text { Group 1 }\end{array}$ & Control Group & $-0.04 \%$ & 0.04 & 1.000 & -0.16 & 0.09 \\
\hline $\begin{array}{l}\text { Treatment } \\
\text { Group 2 }\end{array}$ & Treatment Group 1 & $\begin{array}{c}13.50 \%^{*} \\
(1.80 / \text { large })\end{array}$ & 0.04 & 0.002 & 0.02 & 0.25 \\
\hline \multirow{2}{*}{$\begin{array}{l}\text { Treatment } \\
\text { Group 3 }\end{array}$} & Control Group & $\begin{array}{c}23.13 \%^{*} \\
(3.60 / \text { large })\end{array}$ & 0.03 & 0.000 & 0.14 & 0.32 \\
\cline { 2 - 5 } & Treatment Group 1 & $\begin{array}{c}26.81 \% * \\
(4.12 / \text { large })\end{array}$ & 0.03 & 0.000 & 0.18 & 0.36 \\
\cline { 2 - 5 } & Treatment Group 2 & $\begin{array}{c}13.31 \% * \\
(2.06 / \text { large })\end{array}$ & 0.03 & 0.000 & 0.05 & 0.22 \\
\hline
\end{tabular}

Effect Sizes (Cohen's $d$ ) are indicated in parentheses.

*The mean difference is significant at the 0.008 level.

from each other on the post-test: $\mathrm{F}(3,659)=$ $57.62, p<.001$. To understand which group performed better and the degree of their improvement on the post-test, we conducted post hoc comparisons to compare the performance of pairs of groups, such as a treatment group and the control group, on the post-test. A total of six pairs of comparisons were implemented, which gave rise to the issue of multiple comparisons(in other words, the more hypotheses and comparisons we test, the higher the probability of obtaining at least one false effect positive). A Dunn-Bonferroni test was hence employed as a simple and conservative approach to correct for the number of comparisons (see table 2). The post hoc comparisons with Dunn-Bonferroni corrections $(p=.008)$ indicated that, at the time of the post-test, the mean score for the Treatment Group $3(\mathrm{M}=73.31 \%$, SD = $14.39 \%$ ) was significantly higher than the other three groups: the Control Group (M $=50.18 \%$, SD $=13.71 \%), p<.001$; Treatment Group $1(\mathrm{M}=46.50 \%$, SD $=17.77 \%), p<$ .001 ; and Treatment Group $2(\mathrm{M}=60.00 \%$, $\mathrm{SD}=15.86 \%), p<.001$. Treatment Group 2 also performed significantly better than Treatment Group 1, $p<.008$, but not much better than the control group.
Figure 1 provides a graphic presentation of the changes in scores between the pre- and post-tests. By comparing students' scores in the pre- and post-tests, we note that only students in Treatment Groups 2 and 3 made significant progress in their IL skills. No significant change occurred in the control group or Treatment Group 1. Further results indicated that, prior to receiving any IL instruction at the beginning of the semester, students in the four cohort groups had equally poor IL skills $(\mathrm{M}<51.50 \%)$ and there were no significant difference among these students.

We conducted the same data analyses on each skill area for all cohort groups (see figure 2). All students performed similarly on the pre-test in all eight areas of the IL Skills, but at the time of the post-test, students in Treatment Group 3 performed significantly better than all the other groups in all eight IL Skill areas. From the time of the pre-test to the time of the post-test, students in all four cohort groups made significant improvement in IL Skill 6 (Evaluating Sources). This suggests that this skill might be acquired by students through other means, perhaps on their own. Similarly to their overall information achievement, students in 


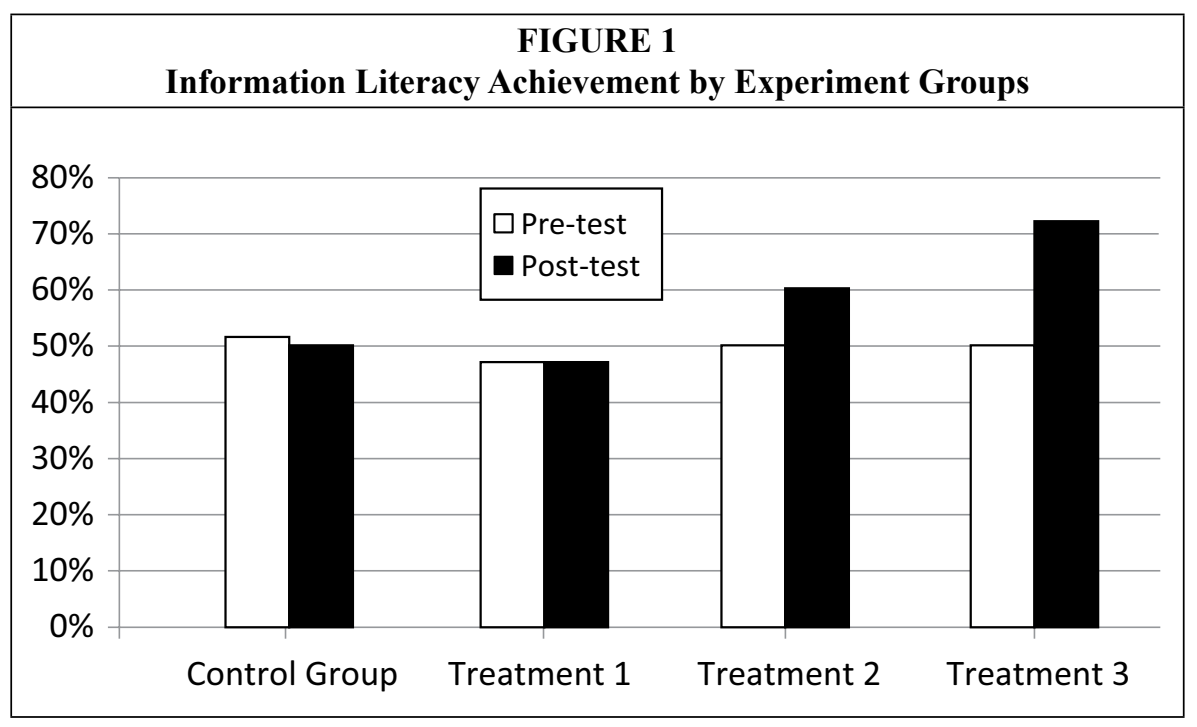

Treatment Group 2 were not consistent in their development of IL Skills. At the time of the post-test, they outperformed the Control Group in IL Skills 3, 5, and 6 and outperformed Treatment Group 1 in Skills 1 and 5, but they failed to demonstrate significantly better performance than these two groups in other skill areas.

When we focus only on the change or progress that occurred to each group, students in Treatment Group 3 made significant progress in all IL Skills except for Skills 4 and 7. These students scored high marks in the pre-test in these same skill sets, so there was little room left for progress in Skills 4 and 7. Students in Treatment Group 2 were able to make significant progress only in IL Skill 3. No other significant acquisition was observed in IL skill areas for students in the Control Group or Treatment Group 1 except for Skill 6.

\section{Discussion}

The results of this study affirm the two research questions we set out to answer: 1. The type of IL instruction does affect student learning outcomes; 2 . The type of instruction students receive affects skill sets differently. The low scores on the pre-test indicate that incoming students enter the university with a need to develop their IL skills. Post-test results show that students do not acquire IL skills on their own even when they are given a research assignment and IL instruction from their English Composition instructor as part of their regular coursework. Students who attended a one-shot librarian-taught session did show some significant gains; however, these gains were not as great as those by students who participated in the online course. These results indicate that IL skills are complex, cognitively challenging skills that need repeated application and practice, ideally as a formal course. The results also show that such a course can be effective when it is delivered fully online.

A great benefit of this study was the ability to test students over a longer period of time compared to similar studies where testing is done immediately after the instruction. This type of testing often leads to conflicting conclusions as to whether results indicate simple memorization of subject matter recently presented or long-term retention of concepts and skills. Since we were able to test students over the course of an entire semester, we can be more confident that students in the ORL course will be able to apply these IL skills when needed in the future.

Results of the study indicate that the one-shot session was helpful in delivering some IL skills and strategies, but it was 


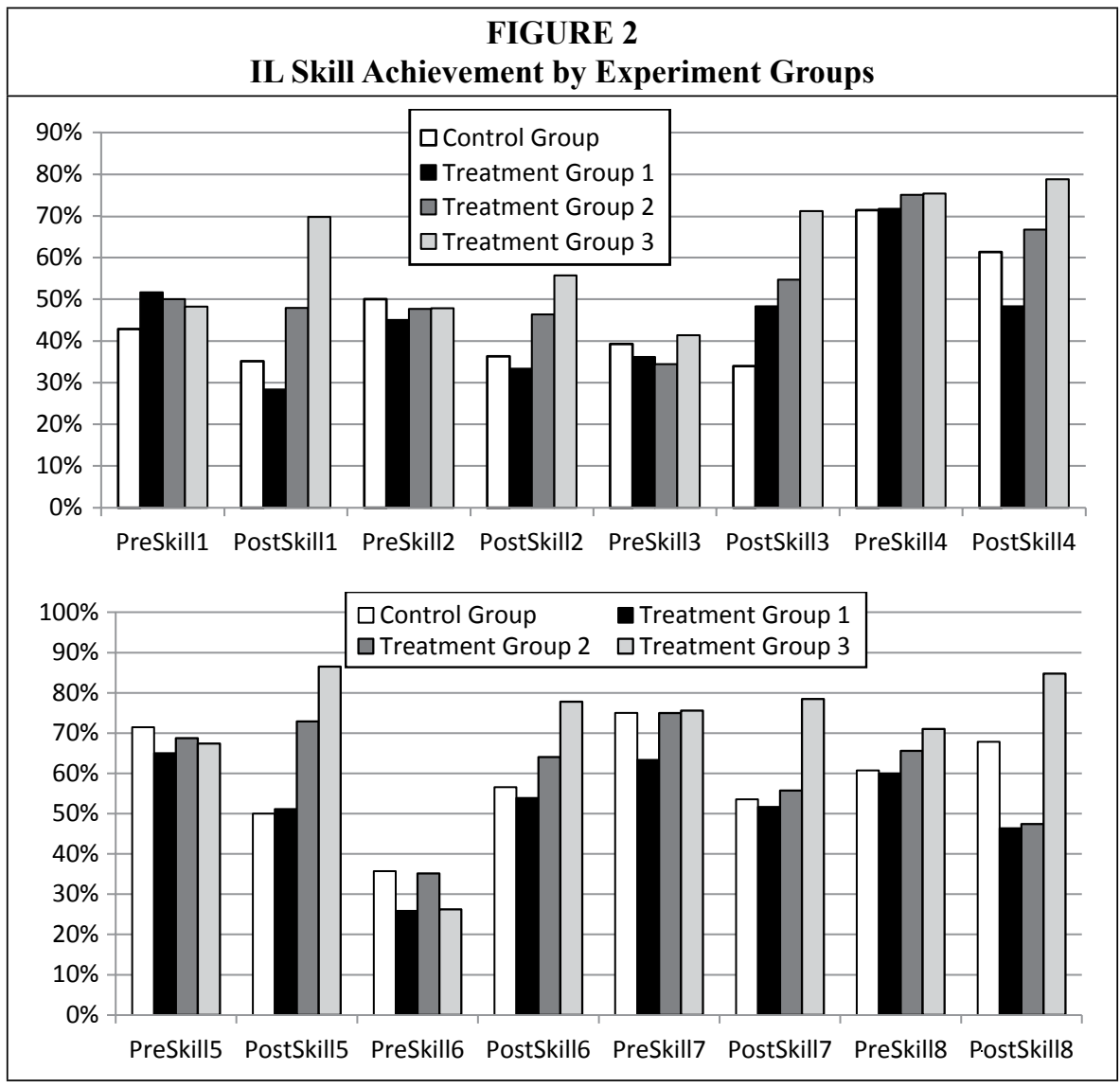

not consistently effective. The one-shot sessions focus on databases and searching and retrieving articles, and these are the areas where students showed the most improvement. Students who participated in the one-shot session did not make significant gains in other skill areas. Comparatively, students who participated in the ORL course showed improvement in all skill areas. As mentioned earlier, all student groups showed improvement in the area of evaluating sources. Many of these questions focus on the evaluation of Web resources. Anecdotal evidence of past student comments and evaluations has shown that students feel comfortable evaluating Web sites and that they have received previous instruction in this area. Since students spend so much time on the Web and use many Web resources for their paper, it makes sense that they have developed these skills on their own.

It should be noted that ORL course students did not show significant improvement in Skills 4 and 7 (Using Finding Tool Features and Documenting Sources). A possible explanation for the lack of progress in Skill 7 is that different English instructors place different emphasis in the documenting of sources. That is, some instructors require strict adherence to a specific citation style (usually, Modern Language Association) while others ask only that the sources be listed in some uniform manner. The explanation for why students did not show significant improvement in Skill 4 is more troublesome. Since the questions used on the pre and post-tests were different but comparable, it is possible that the pre-test 
questions were more difficult than those on the post-test. It is also possible that students did not use the tools enough to recall specific functions of features. Many of these questions focused on databases that students were asked to use later in the semester. Perhaps, since many students had already completed their research for their English course, they did not see a need to use additional databases. We will need to review these questions again and check their reliability and validity.

\section{Limitations}

There are several factors that could have influenced the results and which should be discussed. First, the test, being a multiplechoice test, is limited in what it can tell us about students' information literacy skills. Although test items were matched to skill sets and addressed different levels of cognitive ability from knowledge to analysis, they remain limited in their ability to measure student performance. For example, items cannot measure how efficient a student is at using a particular database or how well they incorporate a particular source into their research paper. To address these and other higher-order skills, the authors have conducted a study that analyzes students' annotated bibliographies.

Second, there was variation in terms of the instruction that students received via their English instructors. All three English instructors were experienced and had been trained by librarians in the past. They all brought their students to the library and conducted a library session. However, researchers did not observe these sessions or gather input about them. It is possible that some instructors continued to give their students more direct instruction in information literacy while others only had the one session.

There was also variation in the difficulty of the test items. To avoid the effect of repeated testing, different sets of questions were created for pre- and post-tests and were used with student groups. This research design was also used because items were being tested for validity and reliability as they were being administered to students to determine learning outcomes. In future research, we suggest that the validity and reliability of test items be tested and validated before any assessment of learning, that all students receive the same items across the cohort groups, and that items are distributed evenly in terms of difficulty level.

Finally, another factor that may have impacted test results was student motivation to do well on the test. For students in the ORL course, both the pre- and posttests had points toward the final grade associated with them. However, students in the other groups did not have this grade incentive. Instead, they received a gift certificate for completing both the pre- and post-tests.

\section{Conclusion}

Pre- and post-tests were administered to 1,400 students in a freshman English composition course using three different modes of instruction. Results showed that students enrolled in the online information literacy course showed a significant improvement in their information literacy skills in a post-test compared to students who received their IL instruction in a one-shot session or through their English Comp grad teaching assistants. In addition, students in the online course performed significantly better in all eight IL skills compared to all test groups.

These results show that information literacy is best taught through a welldesigned online course where students have multiple opportunities to engage with information literacy concepts that they can apply in their English 102 courses and other courses in which they may be enrolled. As a result, the Library Dean and Instructional Services Team Leader were instrumental in advocating to the administration to make the library a credit-bearing academic unit. The online course offers a viable alternative to the face-to-face oneshot session. As Owusu-Ansah ${ }^{34}$ observes, academic librarians must take up the role of teachers and demand that more time 
and focus be given to information literacy to teach information literacy concepts as opposed to focusing on teaching bibliographic search tools and information retrieval. It does require a thoughtful course design based on best practices in online instructional design, the capacity to create online learning modules, and the ability to hire, train, and supervise graduate teaching assistants to meet the need of multiple sections.

\section{Implications for Future Research}

As noted by Fain, ${ }^{35}$ to establish a baseline for expectations of the incoming IL knowledge of freshmen and to understand what kinds of improvements are necessary for instruction, it is necessary to set up a program of longitudinal learning outcomes assessment. The ORL has been offered in each successive semester since the testing began in FY 2010. This testing program will continue in the future. In addition, the authors are interested in learning how well students would do in an "authentic" test of learning, such as how students performed in applying their learning to researching and documenting sources for their term papers.

\section{Notes}

1. Yvonne Mery, Rebecca Blakiston, Elizabeth Kline, Leslie Sult, and Michael Brewer, "Developing an Online Credit IL Course for a Freshman Writing Program in a University Setting," in Best Practices for Credit-Bearing Information Literacy Course, ed. Christopher V. Hollister (Chicago: Association of College and Research Libraries, 2010).

2. Megan Jane Oakleaf, “Using Rubrics to Collect Evidence for Decision-Making: What Do Librarians Need to Learn?" Evidence Based Library and Information Practice 2, no. 3 (Apr. 2007): 27-42, available online at http://ejournals.library.ualberta.ca/index.php/EBLIP [accessed 22 May 2012].

3. Susan L. Silver and Lisa T. Nickel, "Are Online Tutorials Effective? A Comparison of Online and Classroom Library Instruction Methods," Research Strategies 20, no. 4 (2005): 389-96; Elizabeth Mulherrin, Kimberly B. Kelley, Diane Fishman, and Gloria J. Orr, "Information Literacy and the Distant Student: One University's Experience Developing, Delivering, and Maintaining an Online, Required Information Literacy Course," Internet Reference Services Quarterly 9, no. 1/2 (2005): 21-36; Li Zhang, Erin M. Watson, and Laura Banfield, “The Efficacy of Computer-Assisted Instruction Versus Face-to-Face Instruction in Academic Libraries: A Systematic Review," The Journal of Academic Librarianship 33, no. 4 (July 2007): 478-84; Joanna M. Burkhardt, Jim Kinnie, and Carina M. Cournoyer, "Information Literacy Successes Compared: Online Vs. Face to Face," Journal of Library Administration 48, no. 3/4 (2008): 379-89.

4. Elizabeth W. Kraemer, Shawn V. Lombardo, and Frank J. Lepkowski, "The Librarian, the Machine, or a Little of Both: A Comparative Study of Three Information Literacy Pedagogies at Oakland University," College \& Research Libraries 68, no. 4 (July 2007): 330-42.

5. Joan R. Kaplowitz and Janice Contini, “Computer-Assisted Instruction: Is It an Option for Bibliographic Instruction in Large Undergraduate Survey Classes?" College \& Research Libraries 59, no. 1 (Jan. 1998): 19-27.

6. Lucy Holman, "A Comparison of Computer-Assisted Instruction: Is It an Option for Bibliographic Instruction in Large Undergraduate Survey Classes?" Reference E User Services Quarterly 40, no. 1 (2000): 53-60.

7. Paula Webb, "Meeting the Needs of Distance Education Students: Creating an Online-Only Library Instruction Course," College \& Research Libraries News 67, no. 9 (Oct. 2006): 548-50.

8. Zhang, Watson, and Banfield, "The Efficacy of Computer-Assisted Instruction Versus Face-to-Face Instruction in Academic Libraries."

9. Marion Churkovich and Christine Oughtred, "Can an Online Tutorial Pass the Test for Library Instruction? An Evaluation and Comparison of Library Skills Instruction Methods for First Year Students at Deakin University: Smart Searcher Versus Face-to-Face Instruction," Australian Academic \& Research Libraries 33, no. 1 (Mar. 2002): 25-38.

10. Silver and Nickel, "Are Online Tutorials Effective?"

11. Kaplowitz and Contini, "Computer-Assisted Instruction"; Carol Anne Germain, Trudi Jacobson, and Sue A. Kaczor, "A Comparison of the Effectiveness of Presentation Formats for Instruction: Teaching First-Year Students. at SUNY Albany," College E Research Libraries 61, no. 1 (Jan. 2000): 65-72; James Nichols, Barbara Shaffer, and Karen Shockey, "Changing the Face of 
Instruction: Is Online Or in-Class More Effective?" College \& Research Libraries 64, no. 5 (Sept. 2003): 378-88; Burkhardt, Kinnie, and Cournoyer, "Information Literacy Successes Compared"; Karen Anderson and Frances A. May, "Does the Method of Instruction Matter? An Experimental Examination of Information Literacy Instruction in the Online, Blended, and Face-to-Face Classrooms," Journal of Academic Librarianship 36, no. 6 (Nov. 2010): 495-500.

12. Anderson and May, "Does the Method of Instruction Matter?"

13. Kraemer, Lombardo, and Lepkowski, "The Librarian, the Machine, or a Little of Both."

14. U.S. Department of Education, Evaluation of Evidence-Based Practices in Online Learning: A Meta-Analysis and Review of Online Learning Studies (Washington, D.C.: Dept. of Education, 2010).

15. Anderson and May, "Does the Method of Instruction Matter?"

16. Churkovich and Oughtred, "Can an Online Tutorial Pass the Test for Library Instruction?"; C. Gutierrez and J. Wang, "A Comparison of an Electronic Vs. Print Workbook for Information Literacy Instruction," Journal of Academic Librarianship 27, no. 3 (May 2001): 208-12; William Badke, "Ten Reasons to Teach Information Literacy for Credit," Online (Weston, Conn.) 32, no. 6 (Nov./ Dec. 2008): 47-49.

17. Margaret Artman, Erica Frisicaro-Pawlowski, and Robert Monge, "Not Just One Shot: Extending the Dialogue about Information Literacy in Composition Classes," Composition Studies 38, no. 2 (Fall 2010): 93-109.

18. Badke, "Ten Reasons to Teach Information Literacy for Credit."

19. Edward K. Owusu-Ansah, "In Brief Response to Diane Zabel," The Journal of Academic Librarianship 30, no. 1 (2004): 22-23.

20. Rui Wang, "The Lasting Impact of a Library Credit Course," Portal: Libraries and the Academy 6, no. 1 (Jan. 2006): 79-92.

21. Burkhardt, Kinnie, and Cournoyer, "Information Literacy Successes Compared."

22. Joanna M. Burkhardt, "Assessing Library Skills: A First Step to Information Literacy," portal: Libraries and the Academy 7, no. 1 (2007): 25-49.

23. Mulherrin, Kelley, Fishman, and Orr, "Information Literacy and the Distant Student."

24. Diane Zabel, "A Reaction to 'Information Literacy and Higher Education'," The Journal of Academic Librarianship 30, no. 1 (2004): 17-21; Lane Wilkinson and Virginia Cairns, "Life Beyond the One-Shot: Librarians Teaching a for-Credit Course," Tennessee Libraries 60, no. 3 (2010), available online at http://www.tnla.org/displaycommon.cfm?an=1\&subarticlenbr=392 [accessed 15 May 2012].

25. Barbara Wittkopf, "Recreating the Credit Course in an Online Environment: Issues and Concerns," Reference \& User Services Quarterly 43, no. 1 (Fall 2003): 18-25; Tammy S. Sugarman and Laura G. Burtle, "From 50 Minutes to 15 Weeks: Teaching a Semester-Long Information Literacy Course within a Freshman Learning Community," in Integrating Information Literacy into the College Experience, Papers Presented at the Thirtieth National LOEX Library Instruction Conference, eds. Julia K. Nims, Randal Baier, Rita Bullard, and Eric Owen (Ypsilanti, Mich.: Pierian Press, 2002, 2003).

26. Wendy Holliday and Britt Fagerheim, “Integrating Information Literacy with a Sequenced English Composition Curriculum," portal: Libraries and the Academy 6, no. 2 (Apr. 2006): 169-84.

27. Silver and Nickel, "Are Online Tutorials Effective?"; Kraemer, Lombardo, and Lepkowski, "The Librarian, the Machine, or a Little of Both."

28. Kaplowitz and Contini, "Computer-Assisted Instruction"; Silver and Nickel, "Are Online Tutorials Effective?"

29. Kraemer, Lombardo, and Lepkowski, "The Librarian, the Machine, or a Little of Both."

30. John Davis, Mike Odell, Jason Abbitt, and Doug Amos, "Developing Online Courses: A Comparison of Web-Based Instruction with Traditional Instruction," San Antonio, Texas, Feb. 28-Mar. 4, 1999, in Proceedings of SITE 99: Society for Information Technology \& Teacher Education International Conference, eds. Jerry D. Price, Jerry Willis, Dee Anna Willis, Muktha Jost and BogerMehall.

31. Yvonne Mery, Jill Newby, and Ke Peng, "Assessing the Reliability and Validity of Locally Developed Information Literary Test Items," Reference Services Review 39, no. 1 (2011): 98-122.

32. Carolyn J. Radcliff, Lisa G. O'Connor, and Julie A. Gedeon, "Project SAILS Skill Sets for the 2009-2010 Academic Year," Project SAILS, available online at https://www.projectsails.org/ abouttest/skillsets.php?page\%BCaboutTest [accessed 20 April 2010].

33. Dimiter M. Dimitrov and Phillip D. Rumrill, "Pretest-Posttest Designs and Measurement of Change," Work: A Journal of Prevention, Assessment and Rehabilitation 20, no. 2 (2003): 159-65.

34. Owusu-Ansah, "In Brief Response to Diane Zabel."

35. Margaret Fain, "Assessing Information Literacy Skills Development in First Year Students: A Multi-Year Study," The Journal of Academic Librarianship 37, no. 2 (2011): 109-19. 


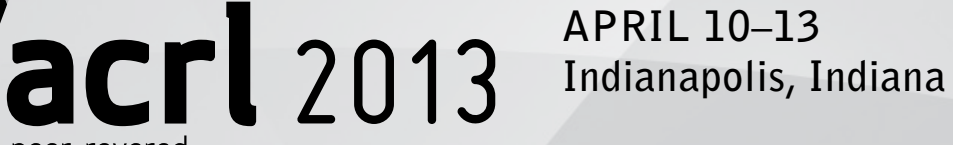 \\ peer revered}

\section{ACRL 2013: Imagine, Innovate, Inspire}

In today's fast-paced and changing world, keeping current is more essential than ever. The ACRL 2013 Conference features more than 300 carefully curated programs to help you stay at the forefront of the profession. Access cutting-edge information, discover new ideas, and engage in conversations with academic and research librarians from around the world at ACRL 2013.

\section{Register now and save!}

Registration and housing materials are now available. Register by the early-bird deadline to take advantage of discounted fees. Save $\$ 70$ or more! Group discounts up to $20 \%$ and scholarships are also available. Materials are online at www.acrl.org/acrlconference.

\section{Keynote Speakers}

Geoffrey Canada, Education Reform Crusader: April 10, 2013-In his 20-plus years with Harlem Children's Zone (HCZ), Geoffrey Canada has become nationally recognized for his pioneering work helping children and families in Harlem and as a passionate advocate for education reform. The work of Canada and HCZ has become a national model and has been the subject of many profiles in the media.

Henry Rollins, Punk Icon/ Activist/ Spoken Word Artist: April 11, 2013-There are many words that describe Henry Rollins but very few that define him. He's been called a punk icon, activist, spoken word artist, author, publisher, photographer, actor, nomad, and raconteur. Rollins famously fronted the hardcore punk band Black Flag and has since released spoken word albums, hosted radio programs, been in several TV shows, and published fifteen books including his latest Occupants, a collection of his travel photography and writings.

Maria Hinojosa, Emmy Award Winning Journalist: April 13, 2013For 25 years, Maria Hinojosa has helped tell America's untold stories and brought to light unsung heroes in America and abroad. As the anchor and managing editor of her own long-running weekly NPR show, Latino USA, and anchor of the Emmy Award winning talk show Maria Hinojosa: One-on-One, Hinojosa has informed millions of Americans about the fastest growing group in our country.
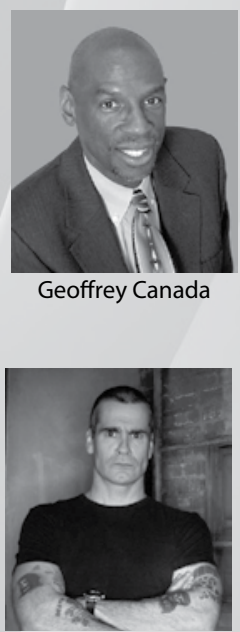

Henry Rollins

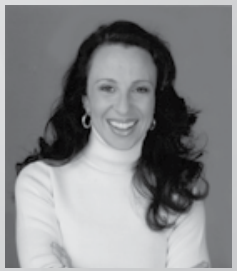

Maria Hinojosa

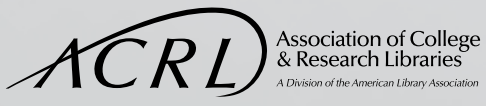

50 E. Huron, Chicago IL 60611 | 1.800.545.2433 www.acrl.org|acrl@ala.org

\section{Connect with ACRL 2013} www.acrl.org/acriconference

Facebook: www.facebook.com/acrl2013

Twitter:@acrl2013 